Revista de
Economild
Contemporâned

\title{
QUALITATIVE INPUT-OUTPUT ANALYSIS OF THE BRAZILIAN STRUCTURAL TRANSFORMATION, 2005 - 2014
}

\author{
Henrique Morrone ${ }^{a}$

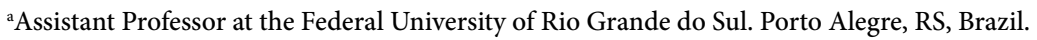 \\ ORCID: https://orcid.org/0000-0001-9579-8489.
}

Received on 27 June 2019

Accepted 27 November 2020

\begin{abstract}
This paper investigates the changes to the essential economic structure of the Brazilian economy from 2005 to 2014. It uses the method of qualitative inputoutput analysis and its extensions, applied by Aroche-Reyes (1996) and Gosh and Roy (1998), to verify the pattern of structural change, the number of dynamic sectors, and to examine whether there has been change in the role of sectors in this period. The results indicate a change in the structure of the economy, leading to a decrease in intersector and intrasector economic linkages. In this context, the construction sector remains central, presenting a substantial number of important coefficients. However, the total number of important coefficients diminished in the whole period, indicating a deteriorated economic structure. This fact points to a restriction in the nation's sustainable economic growth.
\end{abstract}

KEYWORDS: qualitative input-output analysis; development economics.

JEL CODES: O1; C1; D57.

Correspondência para: Henrique Morrone

Contato: hmorrone@hotmail.com 


\section{UMA ANÁLISE QUALITATIVA DE INSUMO-PRODUTO DA TRANSFORMAÇÃO ESTRUTURAL BRASILEIRA, 2005 - 2014}

RESUMO: O objetivo deste trabalho é investigar a evolução qualitativa da estrutura econômica básica da economia brasileira de 2005 a 2014. Utiliza-se o método de análise qualitativa de insumos-produto e suas extensões, aplicado por Aroche-Reyes (1996) e Gosh e Roy (1998), a fim de verificar o padrão de mudanças estruturais, o número de setores dinâmicos e examinar se houve mudança no papel dos setores nesse período. Os resultados indicam uma mudança na estrutura da economia, ocorrendo à redução das ligações intersetoriais e intra-setoriais da economia. Neste contexto, o setor de construção continua sendo central, apresentando um número substancial de coefficientes importantes. Entretanto, o número total de coeficientes importantes diminuiu em todo o período, indicando uma estrutura econômica deteriorada. Este fato aponta para uma restrição no crescimento econômico sustentável da nação.

PALAVRAS-CHAVE: análise de insumo-produto qualitativa; desenvolvimento econômico. 


\section{INTRODUCTION}

Sustainable economic development involves a substantial change towards dynamic activities (those containing scale economies and high labour productivity). The Mercantilist and German economic schools of thought stressed the pivotal role of some sectors to boost economic activity (REINERT, 2005). Structuralists also point in the same direction. Robust growth is achieved through profound structural transformation in the economy (OCAMPO; RADA; TAYLOR, 2009; RONCOLATO; KUCERA, 2013). ${ }^{1}$ Such cases are related to the South Asian growth after the 1950s, e.g., South Korea. There, a structural change towards manufacturing and high tech services emerged (RADA; TAYLOR, 2006). Lack of structural transformation (or a regressive one) is arguably related to stagnation and difficulties in sustaining growth.

There is a large body of input-output research that investigates structural change in the production system. Arguably there are two broad ways to tackle structural change in the economy. Firstly, based on Leontief's (1986) work, more straightforward methods can detect activities with backward and forward linkages. Structural change would be captured by changes in key sectors over time. Chenery and Watanabe (1958) and Rasmussen (1956) estimate sectoral productive interrelations. There are also methodological extensions: triangulation (KORTE; OBERHOFER, 1971), fields of influence (HEWINGS et al., 1989), structural decomposition (SONIS; HEWINGS; GUILHOTO, 1996) and the eigenvector method (DIETZENBACHER, 1992). Marconi, Rocha, and Magacho (2016), Takasago, Mollo, and Guilhoto (2017), and Souza Filho, Santos, and Ribeiro (2020) deal with structural change and the effect of economic policies in Brazil. Overall, these studies rely on sectors' input-output coefficients, concerned mostly with size, number of linkages and propagation length.

An alternative viewpoint can be applied to study structural change and sectors' role in the economy. The qualitative input-output analysis (QIOA) focuses on the existence of fundamental sectoral linkages in the economy. It captures the underlying economic structure of a given economy through direct graphs (AROCHE-REYES; MUNIZ, 2018; GOSH; ROY, 1998). Employing graph theory, researchers can transform the quantitative input-output matrix into a binary matrix (with zeros and ones only) that can be further depicted as a graph. They can use filters to choose the essential intersectoral relationship and shed light on the basic changing structure of an economy. QIOA (at times together with network theory) has applications in mathematics, medicine, physics,

\footnotetext{
1 Taylor (1983) and Ocampo, Rada and Taylor (2009) state that structural change towards manufacturing and high-tech services is key to speed up economic growth.
} 
etc (AROCHE-REYES, 2003). In economics, it is mainly used to examine the economic structure and detect clusters (AROCHE-REYES, 1996; LAHR; DIETZENBACHER, 2001).

QIOA has some advantages over conventional methods when dealing with large matrices and it does not require high quality data (AROCHE-REYES, 2003; BON, 1989). In general, multi-sector models struggle to differentiate the essential linkages between sectors. Since it is hard to deal with all the information in a highly disaggregated matrix, QIOA tries to find only the relevant features of the production system (AROCHEREYES, 2003; AROCHE-REYES; MUÑIZ, 2018). Despite these advantages, there is no superior method in structural analysis (DIETZENBACHER; LOS, 1998).

In this article, we applied the QIOA to investigate Brazilian economy's structural transformation between 2005 and 2014, a period that encompasses most of the last expansionary phase of the business cycle (2002-2014). We employed the methodology developed by Guilhoto and Sesso (2005) to estimate the input-output tables (hereafter refered to as I-O tables) for both years. Data came from the retropolated Make and Use tables made available by the National Statistical Office (IBGE - Instituto Brasileiro de Geografia e Estatística, in Portuguese). Employing these matrices, we transformed the traditional quantitative matrices into adjacency matrices, that is, matrices containing zeros and ones in their entries.

Following the pioneer studies of Yan and Ames (1965) and further contributions from Schintke and Staglin (1988), Gosh and Roy (1998) and Aroche-Reyes (1996, 2003), we estimate the important coefficients (IC) of the Brazilian economy. These coefficients indicate the entries in the technical coefficient matrices " $\mathrm{A}$ " that when changed maintaining the final demand constant - provoke substantial changes in the inverse Leontief matrix and in gross output (JILEK, 1971). Sectors containing several ICs are considered to be dynamic. Economies that evolve over time present a growing division of labour and consequently an increasing number of important coefficients (FORSSEL, 1988). The higher the number of ICs, the more complex and integrated the economic system becomes.

This study can shed light on the essential structural pattern of Brazil, underscoring the more dynamic sectors in the whole period. Assessing different connectivity patterns and their changes could explain better the system's economic performance. Fewer sectoral connections imply difficulties to propagate demand impulses, while large numbers of connections are related with more complex structures (AROCHE-REYES; MUÑIZ, 2018). Moreover, we estimated a centrality index (denoted as the ratio between the incoming edges and outcoming edges for each sector) to find out if there was a substantial change in sectoral roles between 2005 and 2014. To the best of our knowledge, our article is the first to employ QIOA to investigate structural change in Brazil. Hence, this paper tries to fill a void in the literature. 
This paper is organized into four additional sections as follows. Firstly, we briefly review the Brazilian economic performance between 2005 and 2014. The method and data are presented in the second section. The remaining two sections exhibit results and conclusions.

\section{THE BRAZILIAN ECONOMY DURING THE 2000S: A BRIEF OVERVIEW}

The Brazilian economy grew vigorously during the 2000s. It expanded from 2004 to 2010 (per capita GDP rose by $2.8 \%$ per year), even after the effects of the great recession of 2008. Nonetheless, despite recovering part of its dynamism, the country grew slower than in 1950-1973 (UN, 2010).

The external scenario up to 2008 contributed positively to the Brazilian economic performance. The global economy grew significantly, mainly pushed by two Asian economic powerhouses: China and India. They presented impressive output growth rates. As a result, Brazil benefited from rising exports and booming commodities' in the early 2000s. In the 2002-2007 period, commodity prices grew 135\% (MARQUETTI; HOFF; MIEBACH, 2020). The country became less prone to external crises and received a considerable amount of foreign direct investment. The Brazilian economic performance in this period also coincided with the boom in the U.S. economy. When the great recession unfolded, Brazil had international reserves and hence space to implement countercyclical policies. One of the government's responses to the crisis was the drop in the value-added tax on industrialized goods, which boosted aggregate output in the short term (BORGHI, 2017).

The expansion of the Brazilian economy was explained by the internal market's improvement. It resulted from three essential measures. Firstly, the government fostered a plan to improve infrastructure and promote economic development. The Growth Acceleration Plan (PAC - Plano de Aceleração do Crescimento, in Portuguese) aimed at recovering the State's role in planning and coordinating public investments. Secondly, the government employed redistributive policies to boost consumption and increase the level of economic activity. The Bolsa Família program (a family subsidy program) and real increases in the minimum wage were applied in the period. Therefore, an improvement in income distribution emerged. Thirdly, credit supply increased, with State-owned banks leading the process. The amount of credit in relation to GDP augmented substantially from 2000 to 2014 (MARQUETTI; HOFF; MIEBACH, 2020). As a result of these domesticmarket-led policies, unemployment rate fell. The growth in formal employment helped to achieve political and social stability (MORRONE, 2015). 
Despite the growth achieved, the exchange rate overvaluation damaged industry's economic performance. To keep the economy going, the government promoted massive tax cuts to selected sectors and stimulated agglomerations. Moreover, wages increased faster than productivity in the period, putting pressure on firms' markups. The government tried to sustain the investment level by offering subsidized interest rates via state-owned banks. In face of the ongoing deindustrialization (and regressive structural change) and reversion of the rise in commodity prices after 2010, the Worker's Party economic model based on rising domestic activity through a consumption boom and rising international commodity prices started to show its limits by 2014 .

Marconi, Rocha and Magacho (2016) suggest that agricultural and mineral commodity sectors present weak structural links with the rest of the economy. They helped to stimulate short run expansion in Brazil but were unable to foster economic growth. Manufacturing is still the central activity to promote structural change (SOUZA FILHO; SANTOS; RIBEIRO, 2020).

Brazil entered a profound political and economic crisis in 2015. The Gross Domestic Product growth declined from $4.6 \%$ in 2011 to $2.3 \%$ in 2014 (FILGUEIRAS, 2017). The fall in profitability after 2008 halted the class alliance developed during Lula's government (MARQUETTI; HOFF; MIEBACH, 2020), causing the economic downturn and the crisis of 2015. The provision of public goods deteriorated and further contributed to the crisis (PINHEIRO-MACHADO, 2019).

From 2015 to 2020, Brazil presented a sluggish economic performance. The neoliberal agenda was intensified in the new government of Temer, and later with Bolsonaro. Currently, the government has been unable to recover the economy. The Corona-virus outbreak in 2020 is further damaging the economy.

\section{METHODOLOGY AND DATA}

This section presents the model and the data set. First let us exhibit the complete methodology. The antecedents of the model are Schintke and Staglin (1988) and ArocheReyes (1996). Next, we present the data. The main data source to estimate the inputoutput matrices for Brazil was the retropolated Make and Use tables made available by the official statistical office.

\subsection{METHOD}

The country's economic structure can be assessed through a in-depth analysis of a set of activities linked by arcs. The changing basic structure is derived from the evolution 
of new connections and the destruction of old ones. Qualitative input-output analysis (QIOA) serves to track those changes. Usually, graphs are employed to show the interrelations among sectors. An oriented graph showing the direction of demand impulses is known as a digraph (GOSH; ROY, 1998). In networks jargon, a vertex denotes a sector and an edge denote linkages. ${ }^{2}$

Leontief's well known quantitative input-output method was instrumental in undestanding the structure of economies. Its seminal work applied to the American economy opened new branches for future research (LEONTIEF, 1986). Further studies focused on the qualitative aspects of the economic structure, with a view to find the key interindustry linkages and to uncover the distinctive structure of economies. Schintke and Staglin (1988) searched for key economic sectors by analyzing the elemments of tecnhnical coefficients matrix. Their method consisted of finding the cells of the " $\mathrm{A}$ " matrix that when changed provoked major changes in the Leontief matrix and the gross output, while keeping final demand fixed. The entries of the " $\mathrm{A}$ " matrices that cause profound changes in sectoral gross outputs are known as Important Coefficients (ICs).

QIOA and ICs are complementary to the quantitative input-output approach. They exhibit the intersectoral linkages, highlighting the interaction among industries. Identifying ICs helps conventional tecnhiques (for instance, the RAS algorithm) to project I-O matrices in the future (AROCHE-REYES, 1996).

Identifying these cells involves a five-step process to calculate the ICs and the centrality index, denoted as the ratio between the incoming and outcoming edges for each sector. Firstly, the coefficient matrices and the Leontief matrices for 2005 and 2014 must be built. With that purpose, we have chosen Guilhoto and Sesso's (2005) method that builds input-output matrices based on national statistical data.

Next, we follow the standard procedure to select the important coefficients. In this regard we need to create a new matrix using equation (1) (MILLER; BLAIR, 1985). This step involves the estimation of $r_{i j}$ coefficient to each intersectoral transaction.

$$
r_{i j}=\frac{1}{a_{i j}\left[\alpha_{j i}+\left(\alpha_{i i} / \delta_{i}\right) \delta_{j}\right]}
$$

Where:

$a_{i j}=$ an element of the technology direct coefficient matrix (A);

$\alpha_{j i}=$ an element of the inverse Leontief matrix;

$\delta_{i}=$ the output of sector i;

$\delta_{j}=$ the output of sector $\mathrm{j}$.

2 Herein we shall employ the terms industry, sector, vertex, and activities interchangeably. Analogously, arcs, arrows, and directed edges denote similar terms. 
The third step involves applying an exogenous filter to the matrix $r_{i j}$ to create a binary matrix with zeros and ones only. In the literature, this procedure is called a Boolean or Adjacency matrix. The filter is set to be equal to 0.20, or 20\% (AROCHE-REYES, 1996; GOSH; ROY, 1998). Values of the entries of matrix R (containing all the $r_{i j}$ ) smaller than the established filter are ICs. They are set to be equal 1 . They represent stark intersectoral linkages. The remaining less important connections are equal to zero.

De Mesnard (1995) criticizes the Boolean procedure that transforms the technical coefficient input-output matrix into an adjacency matrix. He argues that the filter might throw away important information. Although this might be true in some cases, any researcher can control this possible loss by setting a specific filter (AROCHE-REYES, 1996). This remains an open debate in economics, a problem without any clear consensus or solution to date. In addition, studies have tried to endogenize the filter (SCHNABL, 1994; YAN; AMES, 1965). This endogenous filter depends on the sectoral aggregation employed by the researcher and relies on the matrix order (AROCHE-REYES, 1996; HOWE, 1991). To some extent this is a shortcoming of QIOA. Aroche-Reyes (1996) employed the concept of ICs to overcome this shortcoming.

Fourthly, we plot the Boolean matrix as a directed graph. This graph shows the networks in the economy. For instance, the $\mathrm{Z}$ matrix below depicts the structure of a hypothetical economy. As aforementioned, every element equal to 1 indicates the existence of an IC.

Table 1 - The structure of an economy depicted by an adjacency matrix

\begin{tabular}{lccc}
\hline Sectors & Agriculture & Industry & Services \\
\hline Agriculture & 0 & 1 & 0 \\
$\mathrm{Z}=$ Industry & 1 & 0 & 1 \\
Services & 1 & 1 & 0 \\
\hline Source: Author's own elaboration. & & &
\end{tabular}

Alternatively, the matrix $\mathrm{Z}$ can be expressed as a graph showing structural linkages. An edge emanating from sector " $i$ ” to sector “ $j$ ” indicates that “ $i$ ” is an important supplier of input to “ $j$ ”. This relationship can be displayed by a digraph D as shown in Figure 1. Here, for instance, we can see that services (3) demands inputs from the agriculture (1).

Finally, a centrality index $(\mathrm{G})$ is computed to analyze the role developed by every economic sector. Activities can be users of inputs (sinks) from the rest of the economy, suppliers (sources), or central. A user denotes a sector that absorbs products of the economy; users purchase more inputs from other sectors than they sell. In other words, the in-degree (incoming arrows in the vertex) is larger than the out-degree 
(emanating edges from the vertex). Conversely, source sectors are defined as having in-degrees smaller than out-degrees. A central activity is one that presents equal numbers of in-degrees and out-degrees. Equation (2) shows the method to calculate the centrality index $(G)$.

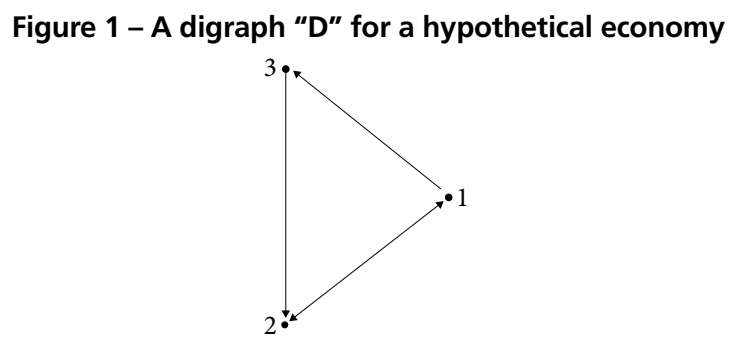

Source: Author's own elaboration.

$$
G=\frac{\text { In-degree }}{\text { Out-degree }}
$$

As aforementioned, a sector can be categorized as a sink, a source or central depending on its value found for the centrality index. Sink sectors present a centrality index larger than 1 . Source sectors exhibit a centrality index smaller than 1. Central sectors display an index equals to 1 .

The centrality indicator allows us to employ comparative statics' analysis. The method of QIOA, in conjunction with ICs and centrality index, gives essential information on the production structure of the economy. QIOA and ICs highlight the basic structure of the network and the dynamic sectors, those containing large number of ICs. The centrality index complements the analysis since it allows an in-depth investigation of the structural transformation, emphasizing the role played by each productive sector of the economy.

\subsection{DATA}

The data set to build the two input-output matrices comes from the Brazilian Statistical Office (IBGE, 2019). Since there was a methodological change in 2010, the official I-O tables for 2005 and 2015 cannot be compared to one another. The official I-O matrix 
for 2005 (reference 2000) follows the System of National Accounts of 1993 (SNA-93), while the I-O for 2015 (reference 2010) uses the SNA-2008.

There are two ways to circumvent this problem. First, we could compare the two official matrices at a highly aggregated level, as suggested by Sousa Filho, Santos, and Ribeiro (2020). This procedure would allow for comparing the two matrices, somewhat reducing (but not eliminating) the bias presented in other comparisons of matrices produced with different methodologies. Nevertheless, it would jeopardize the study of structurally heterogeneous sectors. Moreover, highly aggregated I-O matrices produce another type of bias since activities with different technologies are located in one given sector.

Second, we could estimate disagregated I-O matrices based on data contained in the retropelated Resource and Use Tables (IBGE, 2019), following Guilhoto and Sesso's (2005) methodology. This procedure would allow for comparing the two estimated matrices. However, the use of estimated matrices could also produce some bias in the estimations (MARTINEZ, 2016).

We have chosen to employ the second procedure in our study since it presents the advantage of combining a long period of analysis with highly disagregated sectors. Moreover, there is no official I-O table for 2014 - and this particular year is important as it represents the peak of the last expansionary Brazilian cycle. The retropolated statistics of the Resources and Uses table (containing 107 commodities and 51 activities) provides the pieces of information that are necessary to built the I-O table for 2005 and 2014. ${ }^{3}$ Specifically, we employed this table to estimate the input-output (I-O) matrix following Guilhoto and Sesso (2005). The matrices contain 51 sectors. They are presented in the Appendix. The aggregation of sectors follows the classification employed by the Brazilian Statistical Office (IBGE).

After the computation of the matrices, we applied a Boolean process to find the adjacency matrices, and the filter application followed the method employed by ArocheReyes (1996) and Gosh and Roy (1998). These matrices display linkages that are illustrated by the number one and the lack of interrelation by zeros.

A shortcoming of our study is that the method chosen for estimating the I-O matrices based on national accounts data (GUILHOTO; SESSO, 2005) might produce error, according to Martinez (2016). That is, it might lead to estimations with some bias, a problem that is more related to specific cells than to synthetic measures. This is a drawback of our study.

3 Similarly, Aroche-Reyes (2003) applied QIOA to project I-O matrices for Mexico. 
For consistency's sake and following Lahr and Dietzenbacher (2001), we estimated another IO table for 2010 and compared it with the official one. We found that the mean of technical coefficients of the official table was not significantly, in statistical terms, different from the one estimated. That is, no statistically significant difference between the average of coefficients in the estimations with respect to the official I-O table was found. Moreover, one strength of QIOA is that it does not demand high quality data. Regardless, our results should be taken with caution. ${ }^{4}$

\section{THE STRUCTURAL CHANGE IN BRAZIL BETWEEN 2005 AND 2014}

Figures 2(a) and 2(b) exhibit the "core" structure of the economy in 2005 and 2014. The figures plot the graphs related to the Boolean matrices, depicting the ICs found in both years. Vertices in the figure represent the 51 sectors. Herein an arrow emanating from sector "i" to sector " $j$ " informs us that the former is the input supplier. By the same token, an incoming arrow to sector " $j$ " identifies that this sector is an important user of sector "i". Entries in the main diagonal (Loops) were excluded from the figure to avoid cluttering. Isolated sectors were located outside the orbit. Source sectors are located on the left, whereas sinks are on the right part of the figure. Comparing 2(a) with 2(b) allows us to detect that the matrix became more sparse in 2014 and the number of isolated sectors surged.

In 2014, the adjacency matrix presents a lower density degree when compared with 2005. The density of the matrices reduced from $4.80 \%$ to $4.53 \%$. The density of a matrix reveals the number of arcs in the network as a proportion of the maximum possible number of arcs (NOOY; MRVAR; BATAGELJ, 2011). That is, it is computed as the number of connections actually presented in the network divided by the total number of possible links between sectors (WASSERMAN; FAUST, 1994). When the network system is perfectly connected, it is equal to 1 . Otherwise, sparse networks exhibit density smaller than 1 . The intrasectoral linkages decreased as shown by the reduced number of loops that changed from 31 to 29. In other words, the number of sectors that purchase their own product diminished. The strong intrasectoral linkages presented in oil and natural gas (3), resin manufacturing and elastomers (17) disappeared in 2014. Overall, the underlying structure of the Brazilian economy indicates a lower intersectoral articulation power.

4 The parametric t-test and z-test results are not significant at $1 \%$ and 5\%. The Mann-Whitney U test, a non-parametric test, also indicated that the difference between the means are not statistically significant. Additional results are available on demand. 
Figure 2 - Graphic representations of intersectoral connections for Brazil for 2005 (a) and 2014 (b)

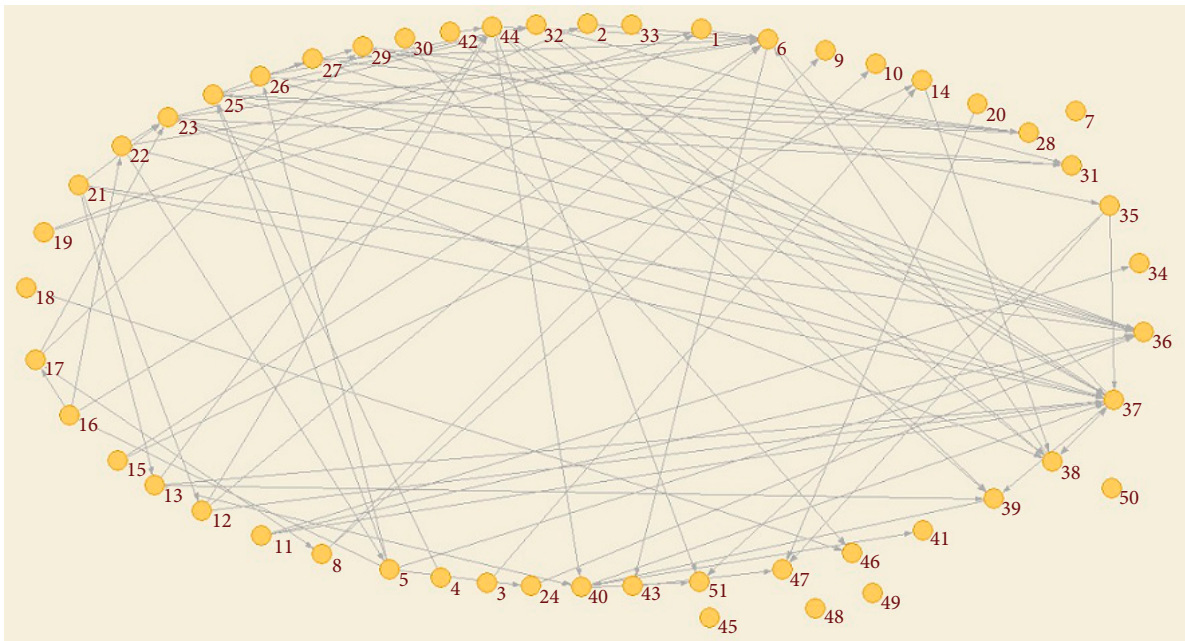

(a)

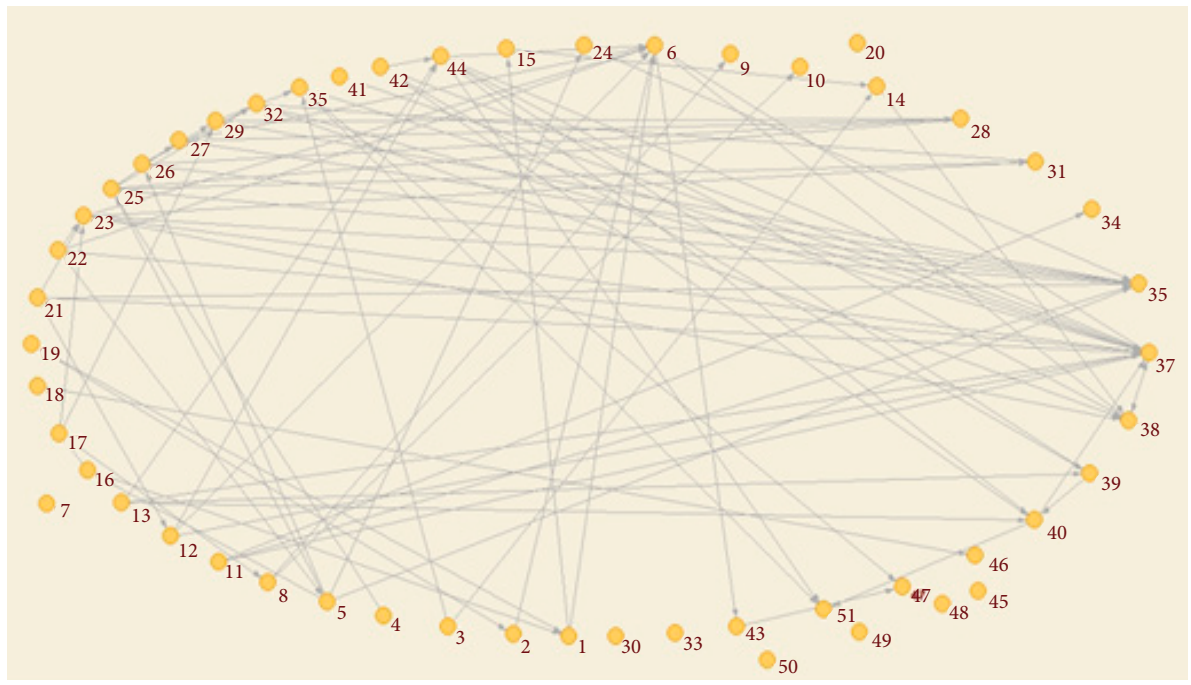

(b)

Note: The network software Pajek was employed in the estimations (MRVAR and BATAGELJ, 1996). Source: Author's own computations.

Table 2 displays the tolerable limits' distribution for the 2601 technology coefficients computed for 2005 and 2014. From 2005 to 2014, the number of important coefficients, 
those denoted by tolerable limits below 0.2 (or 20\%), dropped. ${ }^{5}$ It declined from 125 in 2005 to 118 in 2014, declining 5.6\%. The amount of unimportant coefficients (those containing tolerable limits above $100 \%$ ) increased from 2038 to 2076 (1.86\% increase). Furthermore, when defining border ICs as coefficients with tolerable limits between $20 \%$ and $50 \%$, we detect a decrease from 143 to $141(1.39 \%) .{ }^{6}$ Following this scenario of structural deterioration, the null entries remained relatively constant over the period.

Table 2 - Frequencies' distribution of the tolerable limits for the technology coefficient matrices for Brazil, 2005 and 2014

\begin{tabular}{lccccc}
\hline \multirow{2}{*}{ Ranges $\mathbf{r}$} & \multicolumn{3}{c}{2005} & & \multicolumn{2}{c}{$\mathbf{2 0 1 4}$} \\
\cline { 2 - 3 } \cline { 5 - 5 } \cline { 5 - 5 } & Frequency & Cumulative frequency & & Frequency & Cumulative frequency \\
\hline $0<\mathrm{r}<5$ & $27(1.0)$ & $27(1.0)$ & $24(0.9)$ & $24(0.9)$ \\
$5 \leq \mathrm{r}<10$ & $39(1.5)$ & $66(2.5)$ & $36(1.4)$ & $60(2.3)$ \\
$10 \leq \mathrm{r}<20$ & $59(2.2)$ & $125(4.7)$ & $268(10.2)$ & $58(2.2)$ & $118(4.5)$ \\
$20 \leq \mathrm{r}<50$ & $143(5.5)$ & $461(17.7)$ & & $141(5.4)$ & $235(9.9)$ \\
$50 \leq \mathrm{r}<100$ & $193(7.5)$ & $2499(96.1)$ & & $165(6.4)$ & $400(16.3)$ \\
$\mathrm{r}>100$ & $2038(78.4)$ & $2601(100)$ & & $2076(79.9)$ & $2476(96.2)$ \\
$\mathrm{r}=0$ & $102(3.9)$ & & $101(3.8)$ & $2601(100)$
\end{tabular}

Note: $\left(^{*}\right)$ Numbers in parentheses are percentages.

Source: Author's elaboration based on own estimations.

A comparative statics analysis between 2005 and 2014 from Table 3 gives some insight about changes in the "core" structure of Brazil. There existed 14 different classes (or clusters) in 2005. Cluster values (or classes) denote the number of linkages for each group of vertices in the economy. In 2005, the highest frequency occurs at class 3 (nine vertices are in this class with $17.64 \%$ of the whole distribution located in this class).

5 Eleven stark linkages existed in 2005 that were missing in 2014, while four new linkages appeared in 2014. The linkages that disappeared in 2014 are the following industries: oil and natural gas (3); food and beverages (6); newspapers, magazines, and discs (13); resin manufacturing and elastomers (17); various chemical products and preparations (22); steel manufacturing and derivatives (25); parts and accessories for motor vehicles (32); information services (39); real estate activities and rentals (41); commercial health (46); and services rendered to families and associations (47). Four new connections emerged in 2014 in the following activities: oil and natural gas (3); alcohol (15); commerce (trade) (37); financial intermediation, insurance, and pension plan, and related services (40). We detected a growing activity in sectors such as finance (40) and commerce (37). In short, it seems that a considerable loss of quality in the structure of the Brazilian economy emerged. There were replacements from linkages in sectors known to have high labour productivity (e.g., chemical-related products) to sectors that traditionally are considered to have low productivity.

6 If we restrict our defined border ICs as coefficients with tolerable limits between $20 \%$ and $30 \%$, we verify a considerable decrease from 60 to $45(25 \%)$. 
Classes 0-3 represent $45.09 \%$ of the distribution. The distribution is more sparse in 2014 , with the highest frequency occurring at class 2 (seven vertices are in this class). They represent $13.72 \%$ of the frequency distribution. The frequency distribution for both years is right-skewed, although for the 2014 year, $54.90 \%$ of distribution was located between 0 -4 classes.

Moreover, Table 3 allows us to explore mesoeconomic features of Brazil. Comparing the adjacency matrices for both years and their statistics, we find out that the trade sector (37) has the highest number of connections. It has 17 important linkages with the rest of the economy. The economic model based on consumption might explain, at least partially, this result. Other sectors in this regard are in order of importance: food and beverages (6); business services (44); rubber and plastics (23); steel manufacturing and derivatives (25); transport storage and postal services (38); and parts and accessories for motor vehicles (32). They are mostly from manufacturing or related to it. They show a significant number of strong connections with the economy. For additional details, see the appendix.

Comparing the results of 2005 and 2014, we observe the lack of major changes in the total number of cluster values in Table 3. The largest interconnected sector is again the trade sector (37). In this regard, the new sectors included in 2014 are: construction (36); financial intermediation, insurance, and pension plan, and related services (40); non-ferrous metallurgy (26); and other mining and quarrying (5).

The Brazilian economic model and the distributive policies of the period stimulated a number of service activities. The rise of these activities and the regressive structural change that took place coincided with a more sparce network in 2014. In Brazil's case, these changes are reasonable since the country experienced a construction boom in 2010. In the same vein, financialization and deindustrialization are still an ongoing process on global and national scales. The increased price of commodities arguably also played a part in these results.

Table 3 - Frequencies' distribution of the total linkages for the technology coefficient matrices for Brazil, 2005 and 2014

\begin{tabular}{cccccc}
\hline \multirow{2}{*}{ Cluster values } & \multicolumn{3}{c}{2005} & \multicolumn{2}{c}{$\mathbf{2 0 1 4}$} \\
\cline { 2 - 3 } \cline { 5 - 5 } \cline { 5 - 5 } & Frequency & Cumulative frequency & & Frequency & Cumulative frequency \\
\hline 0 & $5(9.80)$ & $5(9.80)$ & $6(11.76)$ & $6(11.76)$ \\
1 & $5(9.80)$ & $10(19.60)$ & $4(7.84)$ & $10(19.60)$ \\
2 & $4(7.84)$ & $14(27.45)$ & $7(13.72)$ & $17(33.33)$ \\
3 & $9(17.64)$ & $23(45.09)$ & $5(9.80)$ & $22(43.13)$ \\
4 & $3(5.88)$ & $26(50.98)$ & $6(11.76)$ & $28(54.90)$ \\
5 & $4(7.84)$ & $30(58.82)$ & $4(7.84)$ & $32(62.74)$ \\
\hline
\end{tabular}


Table 3 - Frequencies' distribution of the total linkages for the technology coefficient matrices for Brazil, 2005 and 2014

\begin{tabular}{cccccc}
\hline \multirow{2}{*}{ Cluster values } & \multicolumn{3}{c}{2005} & \multicolumn{2}{c}{2014} \\
\cline { 2 - 3 } \cline { 5 - 5 } \cline { 5 - 5 } & Frequency & Cumulative frequency & & Frequency & Cumulative frequency \\
\hline 7 & $6(11.76)$ & $36(70.58)$ & $6(11.76)$ & $38(74.51)$ \\
8 & $5(9.80)$ & $41(80.39)$ & $5(9.80)$ & $43(84.31)$ \\
9 & $3(5.88)$ & $44(86.27)$ & $1(1.96)$ & $44(86.27)$ \\
10 & $1(1.96)$ & $45(88.23)$ & $2(3.92)$ & $46(90.19)$ \\
11 & $1(1.96)$ & $46(90.19)$ & $1(1.96)$ & $47(92.15)$ \\
12 & $2(3.92)$ & $48(94.11)$ & $1(1.96)$ & $48(94.11)$ \\
13 & $1(1.96)$ & $49(96.07)$ & $2(3.92)$ & $50(98.04)$ \\
17 & $1(1.96)$ & $50(98.04)$ & & \\
\hline
\end{tabular}

Source: Author's elaboration based on own elaboration.

Table 4 shows the sectoral characterization for both years. In 2005, there were 24 sources ( $47 \%$ of the total of sectors) and 15 net users of inputs (sinks). Sink sectors receive more demand stimuli than they transmit. Source sectors get less demand impulses than they emit (AROCHE-REYES, 1996). In 2014, the results revealed a slightly lower number of sources (suppliers) while the number of users (sinks) remained constant. Although changes in the aggregate might not appear significant, there were changes in sectoral roles. The same sectors are isolated in both Boolean matrices, except sector 20 (perfumery hygiene and cleanliness) which was a source, becoming isolated in 2014.

With regard to sectors that changed their role over time, five sectors can be emphasized. Agriculture, forestry, and logging (1) changed from sink to central. Sector 15 (alcohol) was a source in 2005, becoming central in 2014. These two sectors gained productive connections in the period, arguibly showing the effect of policies in these segments and positive international conditions. Sector 32 (parts and accessories for motor vehicles) was central initially, later becoming a source. Sector 40, financial intermediation, insurance and pension plan, and related services, passed from central to sink. Sector 41, real estate activities and rentals, was a sink in 2005 and changed to a source in 2014. In short, there was a smaller change in status over the whole period of analysis. The majority of the sectors keept their role in the economy.

Nonetheless, some sectors presented an intensification in their role. The following exhibited a modest increase over time: chemicals (16); rubber and plastic (23); and production and distribution of electricity, gas, water, sewage and urban cleaning (35). The increasing Brazilian dependence on the electricity, gas, water, sewage, and urban cleaning (35), a proxy of the energy sector, might suggest restrictions to long-term 
economic growth. Similar results were found by Aroche-Reyes (1996) for Mexico. Major rises ocurred in sectors such as machinery and equipment, including maintenance and repairs (28), and trade (37). It suggests that the whole economy has become more dependent on these sectors. The majority of the sectors played a reduced role in 2014 . For instance, food and beverages (6) declined in its role as a sink.

Overall, the construction sector was central and remained relevant in the whole period. It is one of the largest sectors in terms of the number of ICs and kept its position. However, one would expect higher qualitative change in this sector since infrastructure has positive impacts on economic growth. Gosh and Roy (1998) found a substantial qualitative change in the Indian construction sector during the 1980s.

Moreover, in general the results might reflect the well-known phenomenon of deindustrialization. Several studies show the decline of manufacturing in Brazil. An overvalued exchange rate and erratic industrial policies have resulted in a diminishing value added share of manufacturing in the whole economy. For a review of the debate, see Oreiro (2014) and Nassif, Bresser-Pereira, and Feijó (2018).

The estimated results, therefore, show a deterioration in the economic structure of Brazil from 2005 and 2014. In line with Marconi, Rocha, and Magacho (2016), and Sousa Filho, Santos, and Ribeiro (2020), the prospect for future growth is bleak. This deteriorated "core" structure suggests potential limits for sustainable economic growth. It also suggests that output growth was slowing down well before the economic and political crisis that stroke Brazil. The results indicate that industries containing high numbers of ICs are dynamic and have power to foster a rapid economic recovery. The government's strategy should focus on these activities to reignite economic output.

Table 4 - Centrality Indexes for Brasil, 2005-2014

\begin{tabular}{llrc}
\hline & Sector & Index 2005 & Index 2014 \\
\hline 1 & Agriculture, forestry, and logging & 2.00 & 1.00 \\
2 & Livestock and fisheries & 1.00 & 1.00 \\
3 & Oil and natural gas & 0.5 & 0.00 \\
4 & Iron ore & 0.00 & 0.00 \\
5 & Other mining and quarrying & 0.20 & 0.20 \\
6 & Food and beverages & 5.50 & 5.00 \\
7 & Tobacco products & isolated & isolated \\
8 & Textiles & 0.67 & 0.67 \\
9 & Articles of apparel and accessories & infinity (b) & infinity (b) \\
10 & Leather goods and footwear & 2.00 & 2.00 \\
11 & Wood products - furniture exclusive & 0.25 & 0.25 \\
12 & Pulp and paper products & 0.50 & 0.50 \\
\hline
\end{tabular}




\begin{tabular}{|c|c|c|c|}
\hline & Sector & Index 2005 & Index 2014 \\
\hline 13 & Newspapers, magazines, and discs & 0.40 & 0.20 \\
\hline 14 & Petroleum refining and coke & 1.50 & 1.50 \\
\hline 15 & Alcohol & 0.00 & 1.00 \\
\hline 16 & Chemical products & 0.50 & 0.67 \\
\hline 17 & Resin manufacturing and elastomers & 0.50 & 0.33 \\
\hline 18 & Pharmaceutical products & 0.50 & 0.50 \\
\hline 19 & Pesticides & 0.33 & 0.33 \\
\hline 20 & Perfumery hygiene and cleanliness & 0.00 & isolated ${ }^{*}$ \\
\hline 21 & Varnishes paints and lacquers & 0.00 & 0.00 \\
\hline 22 & Various chemical products and preparations & 0.40 & 0.20 \\
\hline 23 & Rubber and plastic & 0.57 & 0.67 \\
\hline 24 & Cement and other non- metallic mineral products & 1.00 & 1.00 \\
\hline 25 & Steel manufacturing and derivatives & 0.67 & 0.50 \\
\hline 26 & Non- ferrous metallurgy & 0.40 & 0.40 \\
\hline 27 & Metal products - except machinery and equipment & 0.50 & 0.50 \\
\hline 28 & Machinery and equipment including maintenance and repairs & 2.50 & 5.00 \\
\hline 29 & Appliances and electronic equipment & 0.75 & 0.75 \\
\hline 30 & Office machines and equipment, and electronic materials & 0.50 & 1.00 \\
\hline 31 & Automotive manufacturing & infinity (b) & infinity (b) \\
\hline 32 & Parts and accessories for motor vehicles & 1.00 & 0.75 \\
\hline 33 & Other transport equipment & 1.00 & 1.00 \\
\hline 34 & Furniture and products of various industries & infinity (b) & infinity (b) \\
\hline 35 & Production and distribution of electricity gas, water, sewage, and urban cleaning & 0.50 & 0.75 \\
\hline 36 & Construction & 10.00 & 10.00 \\
\hline 37 & Trade & 3.25 & 4.67 \\
\hline 38 & Transport, storage, and postal services & 2.00 & 2.00 \\
\hline 39 & Information services & 1.67 & 1.33 \\
\hline 40 & Financial intermediation, insurance, and pension plan, and related services & 1.00 & 1.67 \\
\hline 41 & Real estate activities and rentals & infinity (b) & 0.00 \\
\hline 42 & Maintenance and repair services & 0.00 & 0.00 \\
\hline 43 & Accommodation and food services & 1.00 & 1.00 \\
\hline 44 & Business services & 0.71 & 0.71 \\
\hline 45 & Commercial education & isolated $^{*}$ & isolated $^{*}$ \\
\hline 46 & Commercial health & 3.00 & 2.00 \\
\hline 47 & Services rendered to families and associations & infinity (b) & infinity (b) \\
\hline 48 & Domestic services & isolated ${ }^{*}$ & isolated ${ }^{*}$ \\
\hline
\end{tabular}


Table 4 - Centrality Indexes for Brazil, 2005-2014

(Cont.)

\begin{tabular}{llccc}
\hline & & Sector & Index 2005 & Index 2014 \\
\hline 49 & Public education & isolated $^{*}$ & isolated $^{*}$ \\
50 & Public health & isolated $^{*}$ & isolated $^{*}$ \\
51 & Public administration and social security & infinity (b) & infinity (b) \\
\hline
\end{tabular}

Notes: (a) These sectors send no intermediate demand impulses, i.e. their columns contain no ICs. (b) These sectors receive no intermediate demand impulses, i.e. their rows contain no ICs. $\left.{ }^{*}\right)$ These activities have no connections with other sectors. Source: Author's elaboration based on own estimations.

\section{CONCLUSIONS}

This article applied the qualitative input-output analysis (QIOA) to investigate the structural transformation of the Brazilian economy from 2005 to 2014 . We estimated the input-output matrix for both years. Applying the QIOA we pointed out the sectors that contain the higher number of important coefficients. This qualitative method can shed light on the discussions about which sectors should be stimulated.

The results unveil a deteriorated economic structure in the period. The density of the matrices reduced from $4.80 \%$ to $4.53 \%$. The intrasectoral linkages dropped as shown by the diminishing number of loops. The number of important coefficients decreased $5.6 \%$. The amount of less important coefficients (these containing tolerable limits above $100 \%$ ) rose modestly (1.86\%). Additionally, border ICs also decreased over time.

The economies' increasing reliance on the energy sector might indicate restrictions to achieve rapid long-term growth. Moreover, the lack of qualitative change in the construction sector also points towards difficulties to create sustainable growth.

Despite being reasonable, the results found in the study should be interpreted with a grain of salt. As mentioned before, the official I-O tables of 2005 and 2015 are not comparable with one another since a methodological change took place in 2010 . To circumvent this limitation, we estimated highly disagregated I-O matrices based on retropolated data, allowing for comparisons between the 2005 and 2014 matrices. QIOA seems appropriate to analyse the changes in Brazil from 2005 to 2014 since it does not require high quality data (BON, 1989). However, the use of these I-O matrices could produce some biased estimations, which is a shortcoming in our study. The alternative would be high sectoral aggregation, which would otherwise impact negatively on the study of structurally heterogeneous sectors, producing another type of bias instead.

The results thus indicate that governement policies must emphasize strategic sectors. Sectors with high numbers of ICs must be stimulated to guarantee a sustainable expansion. The deteriorated economic structure of Brazil in 2014 suggests challenges for reaching 
robust economic growth. It shows an economy with a lower complexity and with difficulties in sustaining growth. In this regard, the paper gives a mesoeconomic perspective to tackle some problems of Brazil.

\section{REFERENCES}

AROCHE-REYES, F. A qualitative input-output method to find basic economic structures. Papers in Regional Science, v. 82, n. 4, p. 581-590, 2003.

AROCHE-REYES, F. Important coefficient and structural change: a multi-layer approach. Economic Systems Research, v. 8, n. 3, p. 235-246, 1996.

AROCHE-REYES, F.; MUNIZ, A. Modelling economic structures from a qualitative input-output perspective: Greece in 2005 and 2010. Metroeconomica, v. 69, n. 1, p. 251-269, 2018.

BON, R. Qualitative input-output analysis. In: MILLER, R. E.; POLENSKE, K.; ROSE, A. Z. (Eds.). Frontiers of input-output analysis. New York: Oxford University Press, 1989. p. 222-231.

BORGHI, R. The Brazilian productive structure and policy responses in the face of the international economic crisis: An assessment based on input-output analysis. Structural Change and Economic Dynamics, v. 43(C), p. 62-75, 2017.

CHENERY, H.; WATANABE, T. International comparisons of the structure of production. Econometrica, v. 26, n. 4, p. 487-521, 1958.

DE MESNARD, L. A note on qualitative input-output analysis. Economic Systems Research, v. 7, n. 4, p. 439-445, 1995.

DIETZENBACHER, E. The measurement of interindustry linkages: key sectors in the Netherlands. Economic Modelling, v. 9, n. 4, p. 1765-1779, 1992.

DIETZENBACHER, E.; LOS, B. Structural decomposition techniques: sense and sensibility. Economic Systems Research, v. 10, n. 4, p. 307-323, 1998.

FILGUEIRAS, L. Economia, política e o bloco no poder no Brasil. Bahia Análise Dados, v. 27, n. 2, p. 147-173, 2017.

FORSSEL, O. Growth and the changes in the structure of the Finish economy in the 1960s and 1970s. In: CIASCHINI, M. (Ed.). Input-output analysis, current developments. New York: Chapman and Hall, 1988. p. 287-302.

GOSH, S.; ROY, J. Qualitative input-output analysis of the Indian economic structure. Economic Systems Research, v. 10, n. 3, p. 263-274, 1998.

GUILHOTO, J.; SESSO, U. Estimação da matriz insumo-produto a partir de dados preliminares das contas nacionais. Economia Aplicada, v.9, n. 1, p. 1-23, 2005.

HEWINGS, G. et al. Key sectors and structural change in the Brazilian economy: a comparison of alternative approaches and their policy implications. Journal of Policy Modelling, v. 11, n. 1, p. 67-90, 1989.

HOWE, E. Simple industrial complexes. Papers in Regional Sciences, v. 70, p. 71-80, 1991. 
IBGE - INSTITUTO BRASILEIRO DE GEOGRAFIA E ESTATÍSTICA. Sistema de contas nacionais. Tabelas de recursos e usos. Rio de Janeiro: IBGE, 2019. Available at: http://www.ibge.gov.br/ home/estatistica/economia/contasnacionais/2019.

JILEK, J. The selection of most important input coefficients. Economic Bulletin for Europe, v. 23, n. 1, p. 86-105, 1971.

KORTE, B.; OBERHOFER, W. Triangularizing input-output matrices and the structure of production. European Economic Review, v. 2, n. 4, p. 493-522, 1971.

LAHR, M.; DIETZENBACHER, E. Input-output analysis: frontiers and extensions. Basingstone: Palgrave, 2001.

LEONTIEF, W. Input-output economics. New York: Oxford University Press, 1986.

MARCONI, N.; ROCHA, I. L.; MAGACHO, G. Sectoral capabilities and productive structure: an input-output analysis of the key sectors of the Brazilian economy. Brazilian Journal of Political Economy, v.36, n. 3, p.470-492, 2016.

MARQUETTI, A.; HOFF, C.; MIEBACH, A. Profitability and distribution: the origin of the Brazilian political crisis. Latin American Perspectives, v. 47, n. 1, p. 115-133, 2020.

MARTINEZ, T. Método RAWS/RAW para estimação anual da matriz de insumo produto. Pesquisa e Planejamento Econômico, v. 46, n. 2, p. 79-124, 2016.

MILLER, R.; BLAIR, P. Input-output analysis: foundations and extensions. Englewood Cliffs: Prentice-Hall, 1985.

MRVAR, A.; BATAGELJ, V. Pajek. Version XXL. 2020 [1996].

MORRONE, H. Assessing the impact of distributive policies on the Brazilian economy using an SCGE model. Economic Systems Research, v. 27, n. 1, p. 1-18, 2015.

NASSIF, A.; BRESSER-PEREIRA, L. C.; FEIJÓ, C. The case for reindustrialisation in developing countries: towards the connection between the macroeconomic regime and the industrial policy in Brazil. Cambridge Journal of Economics, v. 42, n. 2, p. 355-381, 2018.

NOOY, W.; MRVAR, A.; BATAGELJ, V. Exploratory social network analysis with Pajek. New York: Cambridge University Press, 2011.

OCAMPO, A.; RADA, C.; TAYLOR, L. Growth and policy in developing countries: a structuralist approach. New York: Columbia University Press, 2009.

OREIRO, J. Effects of overvaluation and volalitity of exchange rate over investment in manufacturing industry: empirical evidence and policy proposals for the Brazilian case. Brazilian Journal of Political Economical, v. 34, n. 3, p. 347-369, 2014.

PINHEIRO-MACHADO, R. Amanhã vai ser maior: o que aconteceu com o Brasil e possíveis rotas de fuga para a crise atual. São Paulo: Planeta do Brasil, 2019.

RADA, C.; TAYLOR, L. Developing and transition economies in the late 20th century: diverging growth rates, economic structures, and sources of demand. SCEPA Working Paper n. 2006-1. New York: New School for Social Research, 2006.

RASMUSSEN, P. N. Studies in intersectoral relations. Amsterdam: North-Holland, 1956. 
REINERT, E. German economics as development economics: from the Thirty Year's War to World War II. In: JOMO, K.; REINERT, E. (Eds.). The origins of development economics: how schools of thought have addressed development. New York: Zed Books, 2005. p. 15-36.

RONCOLATO, L.; KUCERA, D. Structural drivers of productivity and employment growth: a decomposition analysis for 81 countries. Cambridge Journal of Economics, v. 38, n. 2, p. 399-424, 2013.

SCHINTKE, J.; STAGLIN, R. Important input coefficients in market transaction tables and production flows tables. In: CIASCHINI, M. (Ed.). Input-output analysis, current developments. New York: Chapman and Hall, 1988. p. 43-60.

SCHNABL, H. The evolution of production structures analysed by a multi-layer procedure. Economic Systems Research, v. 6, n. 1, p. 51-68, 1994.

SONIS, M.; HEWINGS, G.; GUILHOTO, J. Sources of structural change in input-output systems: a field of influence approach. Economic Systems Research, v. 8, n. 1, p. 15-32, 1996.

SOUSA FILHO, J.; SANTOS, G.; RIBEIRO, L. Structural changes in the Brazilian economy 1990-2015. Economic Systems Research, 2020. DOI: 10.1080/09535314.2020.1802234.

TAKASAGO, M., MOLlO, M.; GUILHOTO, J. O debate desenvolvimentista no Brasil: discutindo resultados da matriz de insumo-produto. Planejamento e Políticas Públicas, n. 48, p. 385-409, 2017.

TAYLOR, L. Structuralist macroeconomics: applicable models for the Third World. New York: Basic Books, 1983.

UN - UNITED NATIONS. World economic situation and prospects. New York: UN, 2010.

WASSERMAN, S.; FAUST, K. Social network analysis. Methods and applications. New York: Cambridge University Press, 1994.

YAN, C.; AMES, E. Economic interrelatedness. Review of Economic Studies, v. 32, n. 4, p. 299-310, 1965. 


\section{APPENDIX}

The Input-Output table for Brazil presents 51 activities. The sectors of the disaggregated I-O are: agriculture, forestry, and logging (1), livestock and fisheries (2), oil and natural gas (3), iron ore (4), other mining and quarrying (5), food and beverages (6), tobacco products (7), textiles (8), articles of apparel and accessories (9), leather goods and footwear (10), wood products - furniture exclusive (11), pulp and paper products (12), newspapers, magazines, and discs (13), petroleum refining and coke (14), alcohol (15), chemicals (16), resin manufacturing and elastomers (17), pharmaceutical products (18), pesticides (19), perfumery hygiene and cleanliness (20), enamels varnishes paints and lacquers (21), various chemical products and preparations (22), rubber and plastic (23), cement and other non- metallic mineral products (24), steel manufacturing and derivatives (25), non- ferrous metallurgy (26), metal products - except machinery and equipment (27), machinery and equipment including maintenance and repairs (28), appliances and electronic equipment (29), office machines and equipment, and electronic materials (30), automotive manufacturing (31), parts and accessories for motor vehicles (32), other transport equipment (33), furniture and products of various industries (34), production and distribution of electricity gas water sewage and urban cleaning (35), construction (36), trade (37), transport storage and postal services (38), information services (39), financial intermediation, insurance and pension plan, and related services (40), real estate activities and rentals (41), maintenance and repair services (42), accommodation and food services (43), business services (44), commercial education (45), commercial health (46), services rendered to families and associations (47), domestic services (48), public education (49), public Health (50), and public administration and social security (51). 
Figure A1 - Intersectoral connections for Brazil for 2005 (a) and 2014 (b)

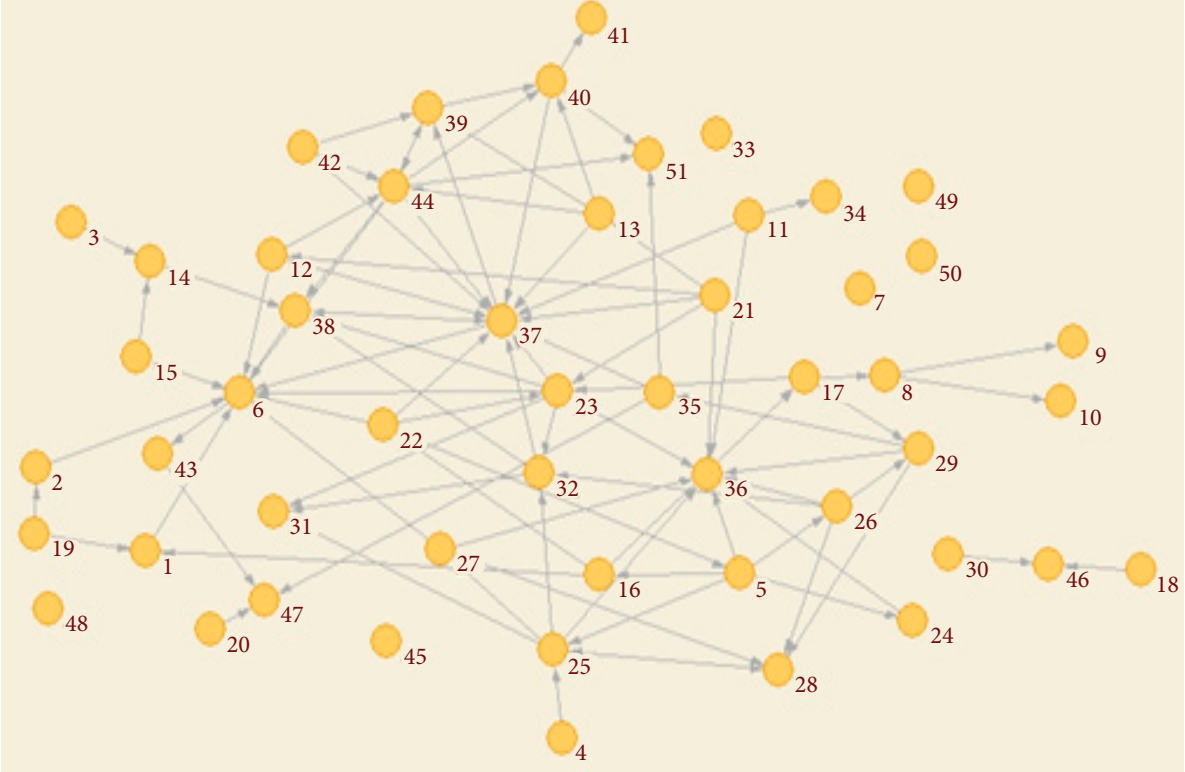

(a)

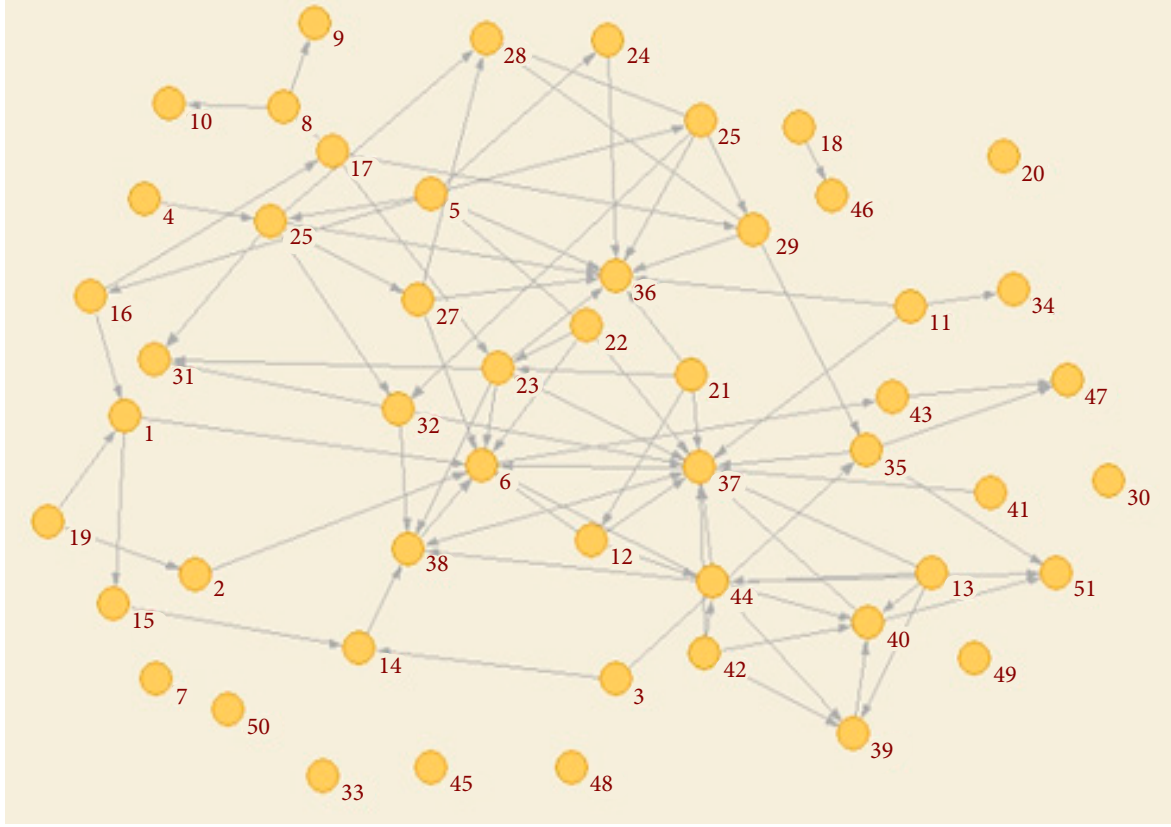

(b)

Source: Author's own computations using the software Pajek (MRVAR and BATAGELJ, 1996). 